\title{
EFFECT OF ORGANIC FERTILIZER RATES AND SULFUR ON GROWTH AND PRODUCTIVITY OF BROAD BEAN UNDER SOUTH SINAI CONDITIONS
}

\author{
Elsagan, Mohamed A.M. ${ }^{*}$ and Suzan M.F. Rashed \\ Department of Plant Production, Desert Research Center, El- \\ Matareya, Cairo, Egypt \\ *E-mail:drm_elsagan@yahoo.com
}

\begin{abstract}
7 he field work was carried out at a private farm at Tour city, South Sinai Governorate, during the two consecutive winter seasons of 2018/2019 and 2019/2020. The experiments were conducted to study the effect of organic manure, soil amendment i.e., $0 ; 25 ; 30$ and $35 \mathrm{~m}^{3} /$ feddan, and four rates of sulfur application i.e., $0 ; 100 ; 150$ and $200 \mathrm{~kg} /$ feddan, where added during soil preparation for planting, on growth, yield and chemical composition of broad bean, Aspany F1 cv., grown in sandy soil conditions. Results revealed that all organic manure treatments showed increase in all growth and yield characters when compared with control treatment in both growing seasons. Organic manure at the rate of 35 $\mathrm{m}^{3} /$ feddan has given significant increase in plant height and weight; number of branches/plant; pods length, pod fresh weight and $\mathrm{N}$; $\mathrm{P}$ and $\mathrm{K}(\%)$, while organic manure at the rate of $30 \mathrm{~m}^{3} /$ feddan had superior significantly effect on number of pods/plant; number of seeds/pod; plant yield and total yield (ton/feddan), followed by organic manure at the rate of $35 \mathrm{~m}^{3} /$ feddan. No significant differences occurred between these two organic treatments in both seasons. Sulfur amendment at the rate of $200 \mathrm{~kg} /$ feddan, followed by the rate of $150 \mathrm{~kg} /$ feddan had got the highest values and significantly increased plant height and weight; number of branches/plant; number of pods/plant, pods length, average pod fresh weight, number of seeds/pod; plant yield; total yield (ton/feddan), as well as $\mathrm{K}$ and $\mathrm{P}(\%)$. There were no significant differences between both treatments in both growing seasons.
\end{abstract}

Keywords: broad bean, organic manure, sulfur, growth, yield

Faba bean (Vicia faba L.) is a major leguminous crop as one of the main important source of protein for the Egyptian people (Nassib et al., 1991). Also, it is a good source of energy and amino acids (Nalle et al., 2010), as well as, its beneficial effect on soil quality and productivity. At the same time, faba bean offers ecosystem services such as renewable inputs of nitrogen into crops and soil via biological ambient $\mathrm{N}_{2}$ fixation (Köpke and 
Nemecek, 2010) and it is thought to be the third important feed grain worldwide (Singh et al., 2013).

Moreover, faba bean cropping might save about $100-200 \mathrm{~kg} \mathrm{~N} \mathrm{ha}^{-1}$ in $\mathrm{N}$ fertilizers needed for crops, which are grown after broad bean (Jensen et al., 2010). In this concern, amending soils with rhizobium and organic amendments can further stimulate root nodulation (Abbas et al., 2011). In Egypt, it is considered as a strategic crop (Hegab et al., 2014).

The horizontal expansionism of agricultural area is one of the solutions to face a growing imbalance between the agricultural production and population increase in Egypt. so about 2.38 million feddans of sandy desert soil could be added to the cultivated area (Ministry of Agriculture and Land Reclamation, 2006). The coarsest texture soils are hard to be productive because of the lower water holding capacity, the higher aeration, the rapid drain, the lower content of the organic matter and the higher fertilizer leaching (El Banna, 1998). In commercial agriculture, the use of chemical fertilizers cannot be ruled out completely. However, there is a need for integrated application for alternate sources for nutrient for sustaining the desired crop productivity (Tiwari, 2002). Recently, the agricultural technology introduced the agricultural nature materials as soil conditioners.

Organic inputs include organic manures, crop residues and biofertilizers. These are low-cost and ecofriendly inputs that have tremendous potential for supplying nutrients, which reduce the dependence of chemical fertilizers. The use of organic soil amendments has been associated with desirable soil properties including higher plant available water holding capacity and cation exchange capacity and lower bulk density and can foster beneficial microorganisms (Doran, 1995 and Drinkwater et al., 1995). Benefits of compost amendments to the soil include $\mathrm{pH}$ stabilization and faster infiltration rate due to enhancing soil aggregation (Stamatiadis et al., 1999).

Organic fertilizers contain organic matter and include a diverse group of materials. Organic manures improve the behaviors of several elements in soils through that active group (fulvic and humic acids), which increase the ability to retain the elements in complex and chelate form. Organic manures release the elements over a period of time and are broken down slowly by soil microorganisms (Ali et al., 2014).

The majority of the nutrients in organic fertilizers are organically bound and slowly mineralized, so the potential for exceeding plant nutrient demands and associated environmental contamination is reduced relative to synthetic commercial fertilization (Stratton et al., 1995). Uses of organic materials are safe for human health and environmental elements. Also, the recycling of organic wastes can also increase soil fertility on the long run through increasing soil organic carbon and the storage of nutrients (Herencia et al., 2008). Also, organic materials improve the physical, chemical and 
biological characteristics of soils, even the poor soil structure of the sodic soils (Farid et al., 2014 and Kamel et al., 2016).

Research has shown that application of FYM or compost has significant impact on the chemical, physical and biological properties of the soil. Most of these effects are due to an increase in soil OM (Souza et al., 2010). Moreover, manure is an excellent source of major plant nutrients such as $\mathrm{N}, \mathrm{P}$ and $\mathrm{K}$, also provides many of the secondary nutrients that plants require. Manure also has a liming effect and neutralizes the acid characteristic of most small holder soils (Nzuma et al., 1998). Also, the improvement in the nodulation, growth and yield characters of faba bean and other legumes from organic amendments has been reported by different researchers (Singh, 2005 and Tadele et al., 2016). In the same line, Osama (2015) indicated that adding of organic substances either alone or in combinations has an effective role on enhancement of studied characters of plant growth; total chlorophyll content; leaf chemical constitutes; flowering pattern; yield components and seed chemical composition of faba bean as compared to the untreated plants. Also, applications of the organic extracts, as well as the compost/biogas tea increased significantly NPK uptake by the growing plants and consequently improved the dry matter yield of faba bean plants (Farid et al., 2018).

Concerning the sulfur needed by legume crops for symbiotic nitrogen fixation, the information is still scarce. Scherer and Lange (1996) observed yield reduction and a lower $\mathrm{N}$ accumulation of grain and fodder legumes under sulfur deficiency conditions. For this reason, Lange (1998) stated that growth of leguminous plant species may be affected by sulfur through its effect on $\mathrm{N}_{2}$ fixation by Rhizobium bacteria. Also, the role of sulfur in legumes growth is important from the point of view that deficiency of the Scontaining amino acids cysteine and methionine may limit the nutritional value of food and feed (Sexton et al., 1998). Sulfur has occupied an important place - after nitrogen, phosphorus, and potassium in balanced fertilization programs due to use of sulfur-free fertilizers (Mukherjee and Singh, 2002).

As numerous research studies show, shortage of sulfur component in the soil reduces the yield and seed quality of pulses (Tabe and Higgins, 1998 and Głowacka et al., 2019). Sulfur also plays a vital role in $\mathrm{N}_{2}$ fixation (Kaiser et al., 2005 and Mendel and Bittner, 2006). Elemental S is a relatively new fertilizer used in agriculture, therefore its impact on the yield and chemical composition of plants is not yet fully known. Fertilizer not only is a source of $\mathrm{S}$ for plants after oxidation, but also considerably changes soil properties by acidifying (Zhou et al., 2009). Thus, it can alter the availability of minerals, including $\mathrm{K}$. Elemental $\mathrm{S}$, as a nutrient carrier and a component initiating many microbiological processes in soil, it is a significant factor in metabolic and physiological changes in legume yields (Niewiadomska et al., 2015). 


\section{MATERIALS AND METHODS}

The field work was carried out at a private farm at Tour city, South Sinai Governorate, during the two consecutive winter seasons of 2018/2019 and 2019/2020. The physical and chemical soil characteristics of the studied site were determined according to Page et al. (1982) and Klute (1986) respectively, as recorded in table (1). The chemical analysis of irrigation water was carried out using the standard method of Page et al. (1982) and presented in table (2). In addition, the organic manure analysis presented in table (3).

Table (1). Some Physical and chemical properties of the experimental soil site.

\begin{tabular}{|c|c|c|c|c|c|c|c|c|c|c|}
\hline \multirow{2}{*}{$\begin{array}{c}\text { Soil } \\
\text { depth } \\
(\mathrm{cm})\end{array}$} & \multirow{2}{*}{$\begin{array}{l}\text { Texture } \\
\text { class }\end{array}$} & \multicolumn{3}{|c|}{ Soluble anions (me/l) } & \multirow{2}{*}{$\begin{array}{c}\text { pH } \\
\text { of soil } \\
\text { paste }\end{array}$} & \multirow{2}{*}{$\begin{array}{c}\text { E.C } \\
\text { dSm }^{-1}\end{array}$} & \multicolumn{4}{|c|}{ Soluble cations (me/l) } \\
\hline & & $\mathrm{HCO}_{3}^{-}$ & $\mathrm{SO}_{4}{ }^{=}$ & $\mathrm{Cl}^{-}$ & & & $\mathrm{Ca}^{+2}$ & $\mathbf{M g}^{+2}$ & $\mathbf{N a}^{+}$ & $\mathbf{K}^{+}$ \\
\hline $0-30$ & $\begin{array}{l}\text { Sandy } \\
\text { loam }\end{array}$ & 2.10 & 17.65 & 23.64 & 7.24 & 4.36 & 8.23 & 12.56 & 20.20 & 2.4 \\
\hline
\end{tabular}

pH: Acidity, E.C.: Electrical conductivity, me/l: milli equivalent per liter

Table (2). Chemical analysis of the irrigation water.

\begin{tabular}{|c|c|c|c|c|c|c|c|c|}
\hline \multicolumn{3}{|c|}{ Soluble anions (me/l) } & \multirow{2}{*}{$\begin{array}{c}\text { pH } \\
\text { of soil } \\
\text { paste }\end{array}$} & \multirow{2}{*}{$\begin{array}{l}\text { E.C } \\
\text { dSm }^{-1}\end{array}$} & \multicolumn{4}{|c|}{ Soluble cations (me/l) } \\
\hline $\mathrm{HCO}_{3}^{-}$ & $\mathrm{SO}_{4}{ }^{=}$ & $\mathrm{Cl}^{-}$ & & & $\mathrm{Ca}^{+2}$ & $\mathbf{M g}^{+2}$ & $\mathbf{N a}^{+}$ & $\mathbf{K}^{+}$ \\
\hline 1.44 & 1.89 & 4.37 & 0.77 & 7.88 & 2.6 & 3.86 & 0.78 & 0.46 \\
\hline
\end{tabular}

pH: Acidity, E.C.: Electrical conductivity, $\mathrm{dSm}^{-1}$ : decseime per meter.

Table (3). Analysis of organic manure used.

\begin{tabular}{lccccccc}
\hline Season & $\begin{array}{c}\text { Moisture } \\
\mathbf{( \% )}\end{array}$ & $\begin{array}{c}\text { Organic } \\
\text { matter } \\
(\%)\end{array}$ & $\begin{array}{c}\text { Total } \\
\mathbf{C} \%\end{array}$ & $\begin{array}{c}\text { C/N } \\
\text { ratio }\end{array}$ & $\begin{array}{c}\text { Total } \\
\mathbf{N} \%\end{array}$ & $\begin{array}{c}\text { Total } \\
\mathbf{P} \%\end{array}$ & $\begin{array}{c}\text { Total } \\
\mathbf{K \%}\end{array}$ \\
\hline 2019 & 11.59 & 22.07 & 14.25 & 9.69 & 1.47 & 0.85 & 1.34 \\
2020 & 10.40 & 20.65 & 13.47 & 10.44 & 1.29 & 0.87 & 1.45 \\
\hline
\end{tabular}

The experiments have been performed to investigate the effect of organic manure amendment and sulfur application rates on growth, yield and its components in addition to chemical composition of broad bean plants (Vicia faba) grown under sandy soil conditions and drip irrigation system. Sixteen treatments represented a combination of four organic manure rates i.e., $0,25,30$ and $35 \mathrm{~m}^{3} /$ feddan (cattle manure). Also, four rates of agricultural sulfur at the rate of $0,100,150$ and $200 \mathrm{~kg} /$ feddan, were applied during preparation of soil for planting. 
Calcium super phosphate $\left(15.5 \% \mathrm{P}_{2} \mathrm{O}_{5}\right)$ at the rate of $300 \mathrm{~kg} /$ feddan, were added during land preparation. Potassium sulphate $\left(48 \% \mathrm{~K}_{2} \mathrm{O}\right)$ at the rate of $150(\mathrm{~kg} /$ feddan $)$ and ammonium sulphate $(20.5 \% \mathrm{~N})$ at the rate of 100 ( $\mathrm{kg} /$ feddan) fertilizer quantities were divided and applied within drip irrigation system starting after 30 days from planting to end of maturity. While, broad bean seeds Aspany F1 c.v. were sown in the first week of October through the two growing seasons, respectively.

Experimental plot area was $32 \mathrm{~m}^{2}$ ( $4 \mathrm{~m}$ wide $* 8 \mathrm{~m}$ long), formed of four ridges, each ridges width is $60 \mathrm{~cm}$ and had one drip irrigation line. Broad bean seeds were soaked in warm water 6 hours before planting and treated by Rhizobium bacteria (purchased from the General Authority of Agricultural Funds and Equalization) then planted within two lines for each ridge $25 \mathrm{~cm}$ apart between seeds. All agricultural practices for broad bean crop were followed, according to the recommendation of Egyptian Ministry of Agriculture.

\section{Growth Parameters of Vegetative Growth}

After 90 days from planting, nine plants of each replicate were randomly taken for recording vegetative growth and yield characteristics, i.e., plant height and weight; number of branches/plant; number of pods/plant, pods length and weight, number of seeds/pod and plant yield. In addition, all harvest times were weighted and calculated to calculate total yield (ton/feddan) from each treatment.

\section{Chemical Composition}

Three samples of bean pods from each subplot were taken and oven dried at $70^{\circ} \mathrm{C}$ until stable weight obtained, then ground to fine particles and used to determine chemical content such as minerals, (N, P and $\mathrm{K}$ ), Phosphorus was determined using the colorimetric method for phosphorus content using spectrophotometer according to Cottenie et al. (1982). Total nitrogen was determined using the modified micro Kjeldahl method, Potassium percentage was measured using flame photometer method as described by Brown and Lilliland (1964).

\section{Experimental Design and Statistical Analysis}

The experimental treatments were arranged in split plot design with three replicates, the main plots were assigned for organic manure, whereas, agriculture sulfur treatments rates were randomly arranged in the sub plots. Statistical analyses of obtained data were analyzed according to Thomas and Hills (1975). 


\section{RESULTS AND DISCUSSION}

\section{Plant Growth and Yield Parameters}

Data in tables (4-6) concerning the growth and yield parameters, i.e., plant height and weight; number of branches/plant; number of pods/plant, pods length, average pod fresh weight, number of seeds/pod; plant yield and total yield (ton/feddan). Results indicated that there were significant positive effects for both organic manure and sulfur application on all investigated growth parameters. The data could remark the following:

- Generally, all organic manure treatments showed increase in all growth and yield characters when compared with control treatment in both growing seasons. Organic manure at the rate of $35 \mathrm{~m}^{3} /$ feddan has shown significant superiority on plant height and weight; number of branches/plant; pods length and weight when compared with control treatment. Also, organic manure at the rate of $30 \mathrm{~m}^{3} /$ feddan were superior significantly on number of pods/plant; number of seeds/pod; plant yield and total yield (ton/feddan). There are no significant differences occurred between those two organic treatments in both seasons. Improvement effect of organic manure may be due to the role of organic manure in increasing soil organic carbon and the storage capacity of nutrients (Herencia et al., 2008); improving the chemical, physical and biological properties of the soil (Souza et al., 2010); increasing available water holding capacity, cation exchange capacity; lowering bulk density and improving the behaviors of several elements in soils (Ali et al., 2014). The obtained results are in the same line with those reported by Singh (2005), Osama (2015), Tadele et al. (2016) and Farid et al. (2018). They found that organic amendments showed improvement in the nodulation, growth and yield characters of broad bean and other legumes.

- Sulfur treatments generally showed improvement of values in all growth and yield parameters when compared with control treatment. At the rate of $200 \mathrm{~kg} /$ feddan, followed by the rate of $150 \mathrm{~kg} /$ feddan, sulfur amendment had the highest values and significant increased the plant height and weight; number of branches/plant; number of pods/plant, pods length, average pod fresh weight, number of seeds/pod; plant yield and total yield (ton/feddan) and there were no significant differences between both treatments in both seasons. The role of sulfur in legumes growth is important from the point of view that deficiency of the S-containing amino acids cysteine and methionine may limit the nutritional value of food and feed (Sexton et al., 1998). Also, sulfur plays a vital role in $\mathrm{N}_{2}$ fixation (Kaiser et al., 2005 and Mendel and Bittner, 2006). Thus, it can alter the availability of minerals, including $\mathrm{K}$. Elemental $\mathrm{S}$, as a nutrient carrier and a component initiating many microbiological processes in soil, is a significant factor in metabolic and physiological changes in legume

Egyptian J. Desert Res., 70, No. 2, 137-151 (2020) 


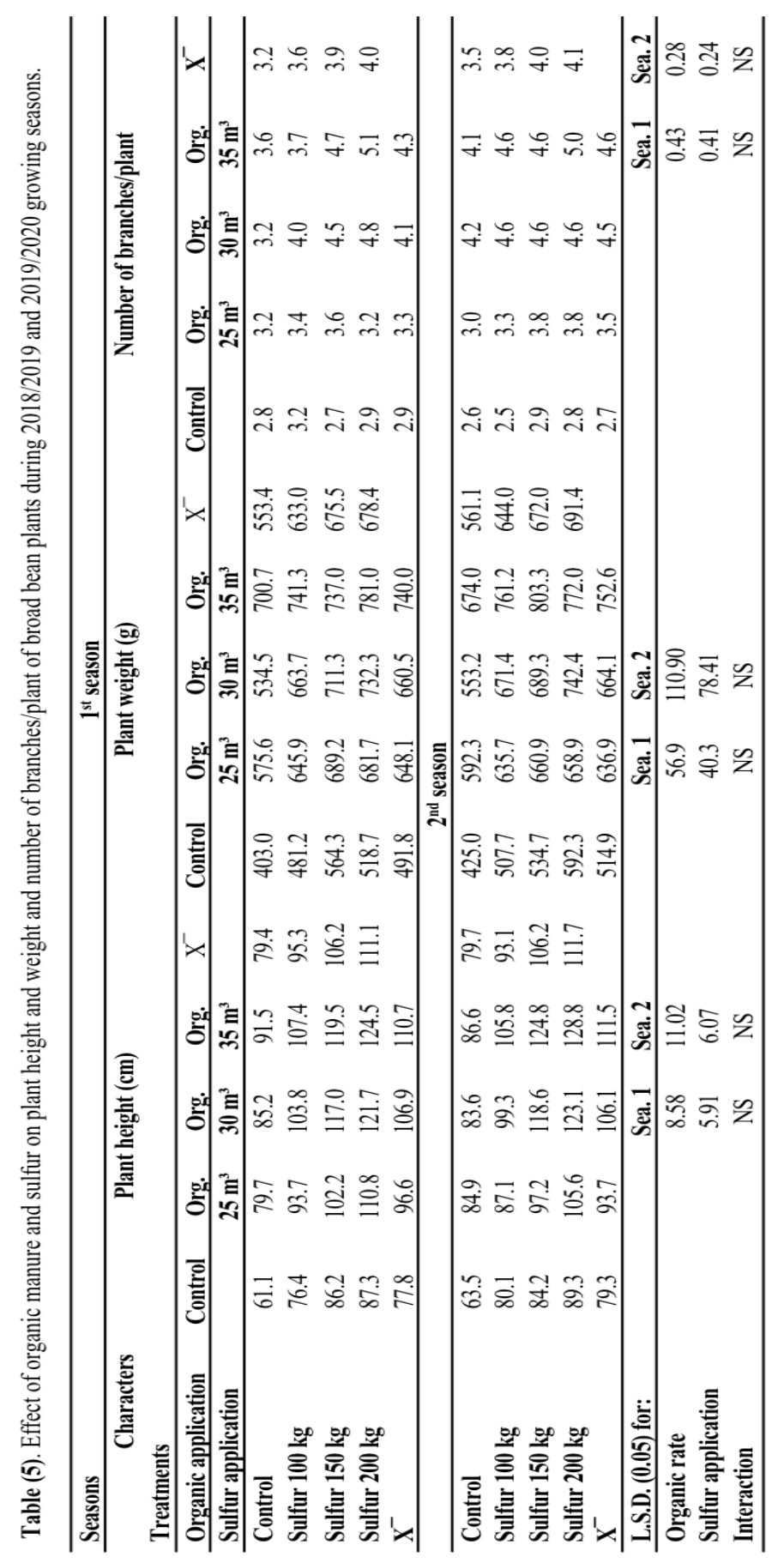

Egyptian J. Desert Res., 70, No. 2, 137-151 (2020) 


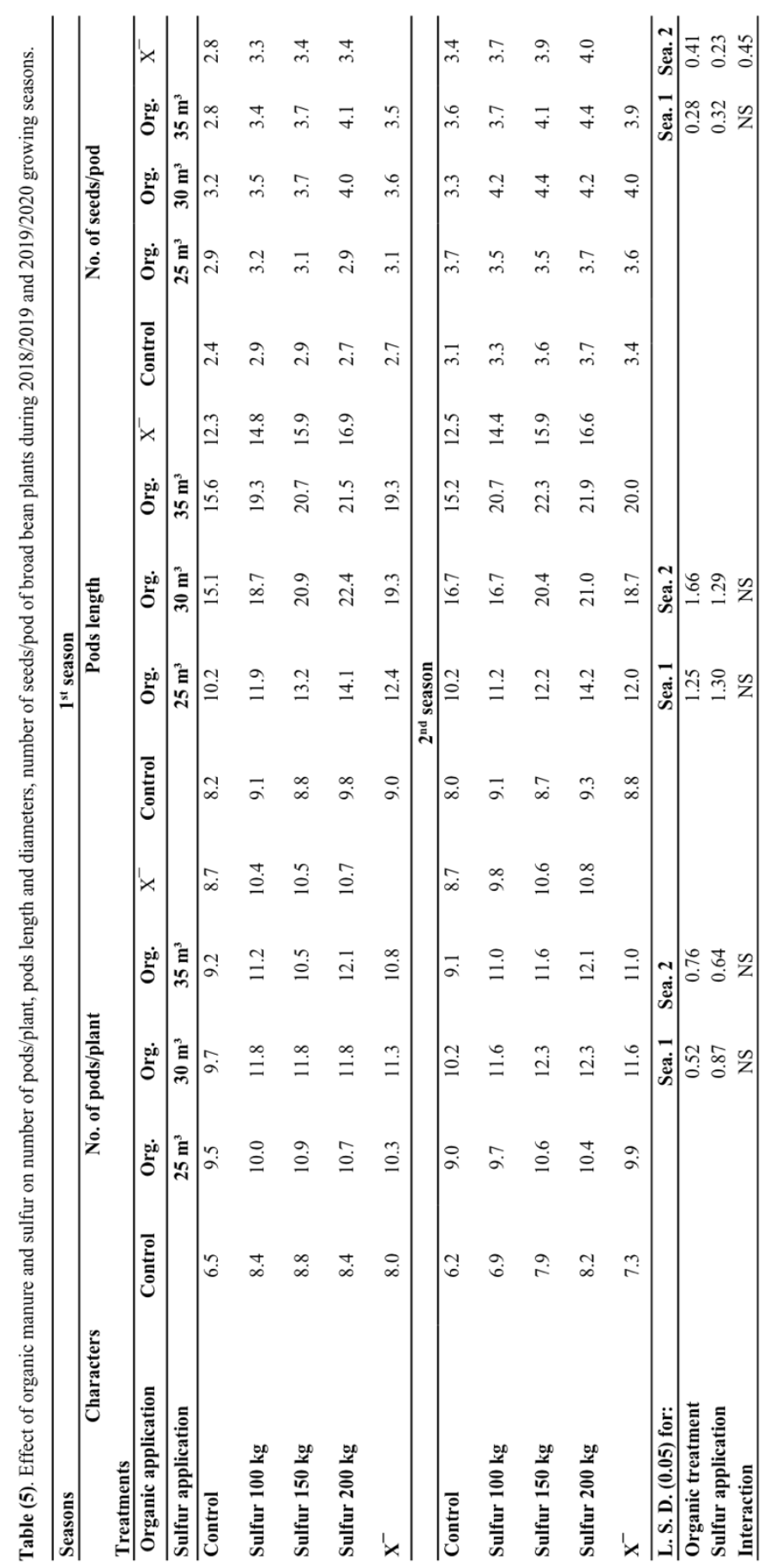

Egyptian J. Desert Res., 70, No. 2, 137-151 (2020) 


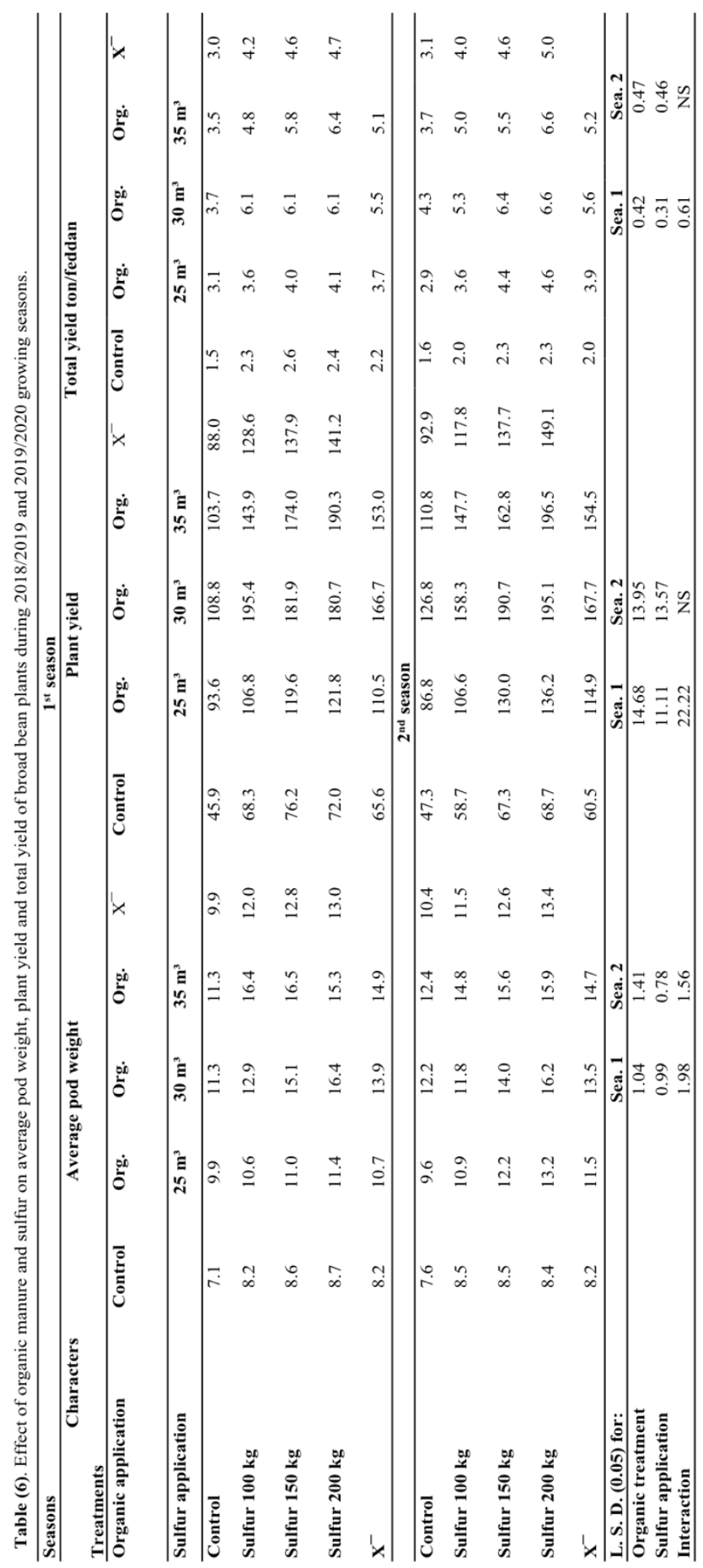

Egyptian J. Desert Res., 70, No. 2, 137-151 (2020) 
yields (Niewiadomska et al., 2015). These results agree with those reported by Scherer and Lange (1996), who observed yield reduction and a lower $\mathrm{N}$ accumulation in grain and fodder legumes under $\mathrm{S}$ deficiency conditions. Also, Lange (1998) stated that growth of leguminous plant species may be affected by $\mathrm{S}$ through its effect on $\mathrm{N}_{2}$ fixation by Rhizobium bacteria.

- The interaction effect showed that the highest values of the number of seeds/pod were recorded with organic manure at the rate of $35 \mathrm{~m}^{3} /$ feddan + sulfur at the rate of $200 \mathrm{~kg} /$ feddan and organic manure at the rate of 30 $\mathrm{m}^{3} /$ feddan + sulfur at the rate of $150 \mathrm{~kg} /$ feddan in the second season only. While, the heighest values of average pod weight were recorded with organic manure at the rate of $35 \mathrm{~m}^{3} /$ feddan + sulfur at the rate of 150 $\mathrm{kg} /$ feddan in the first season and with organic manure at the rate of 30 $\mathrm{m}^{3} /$ feddan + sulfur at the rate of $200 \mathrm{~kg} /$ feddan in the second season. Moreover, the combination treatment between organic manure at the rate of $30 \mathrm{~m}^{3} /$ feddan + sulfur at the rate of $100 \mathrm{~kg} /$ feddan and organic manure at the rate of $35 \mathrm{~m}^{3} /$ feddan + sulfur at the rate of $200 \mathrm{~kg} /$ feddan showed the highest values significantly on plant yield and total yield, respectively, in the first season only.

\section{Chemical Composition}

Obtained results in fig. (1) indicate significant positive effect for both studied factors, i.e., organic manure and sulfur application on chemical components. From the obtained data, the following could be remarked:

- Organic manure at the rate of $35 \mathrm{~m}^{3} /$ feddan was superior significantly on $\mathrm{N}$; P and $\mathrm{K}(\%)$, followed by organic manure at the rate of $30 \mathrm{~m}^{3} /$ feddan without significant differences when compared with control treatment in both seasons. These results are in the same line with those reported by Farid et al. (2018), who found that application of the organic extracts, as well as the compost/biogas tea increased significantly NPK uptake by the grown plants and consequently improved the dry matter yield of faba bean plants.

- Sulfur treatments showed improvement of the values of chemical content. Also, sulfur amendment at the rate of $200 \mathrm{~kg} /$ feddan, followed by the rate of $150 \mathrm{~kg} /$ feddan had the highest values and significant increased $\mathrm{K}$ and $\mathrm{P}$ $(\%)$ in the first season only. Also, sulfur amendment at the rate of 150 $\mathrm{kg} /$ feddan, followed by the rate of 200 had the highest values of $\mathrm{N} \mathrm{( \% )} \mathrm{on}$ the first season only. The growth of leguminous plant species may be affected by $\mathrm{S}$ through its effect on $\mathrm{N}_{2}$ fixation by Rhizobium bacteria. Also, the role of sulfur in legumes growth is important from the point of view that deficiency of the S-containing amino acids cysteine and methionine may limit the nutritional value of food and feed (Lange, 1998 and Sexton et al., 1998).

Egyptian J. Desert Res., 70, No. 2, 137-151 (2020) 
Frist season

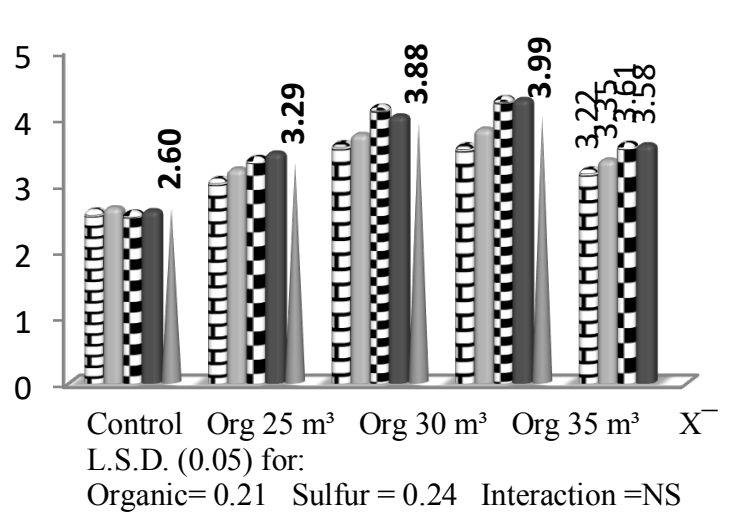

Second season

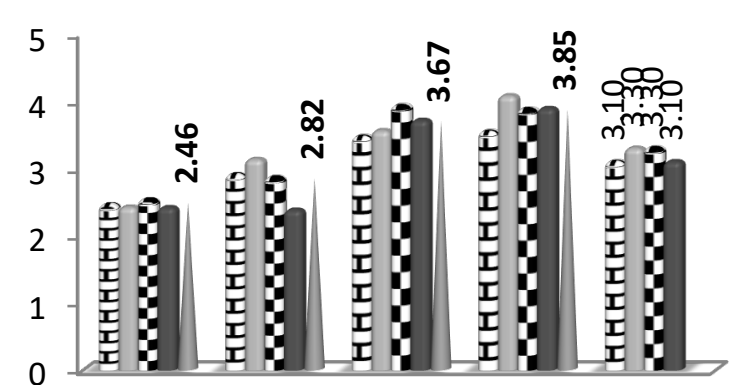

Control Org $25 \mathrm{~m}^{3} \quad$ Org $30 \mathrm{~m}^{3} \quad$ Org $35 \mathrm{~m}^{3} \quad \mathrm{X}^{-}$ L.S.D. (0.05) for:

Organic $=0.21$ Sulfur $=$ NS Interaction $=$ NS

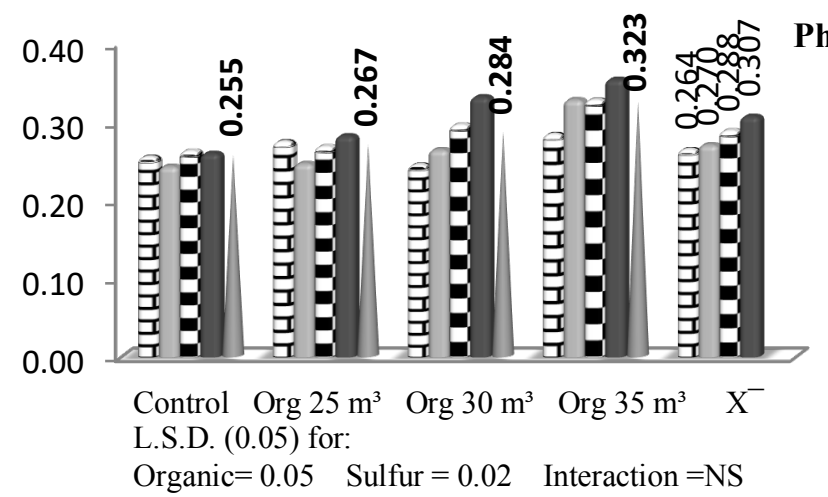

Phosphorus (\%)
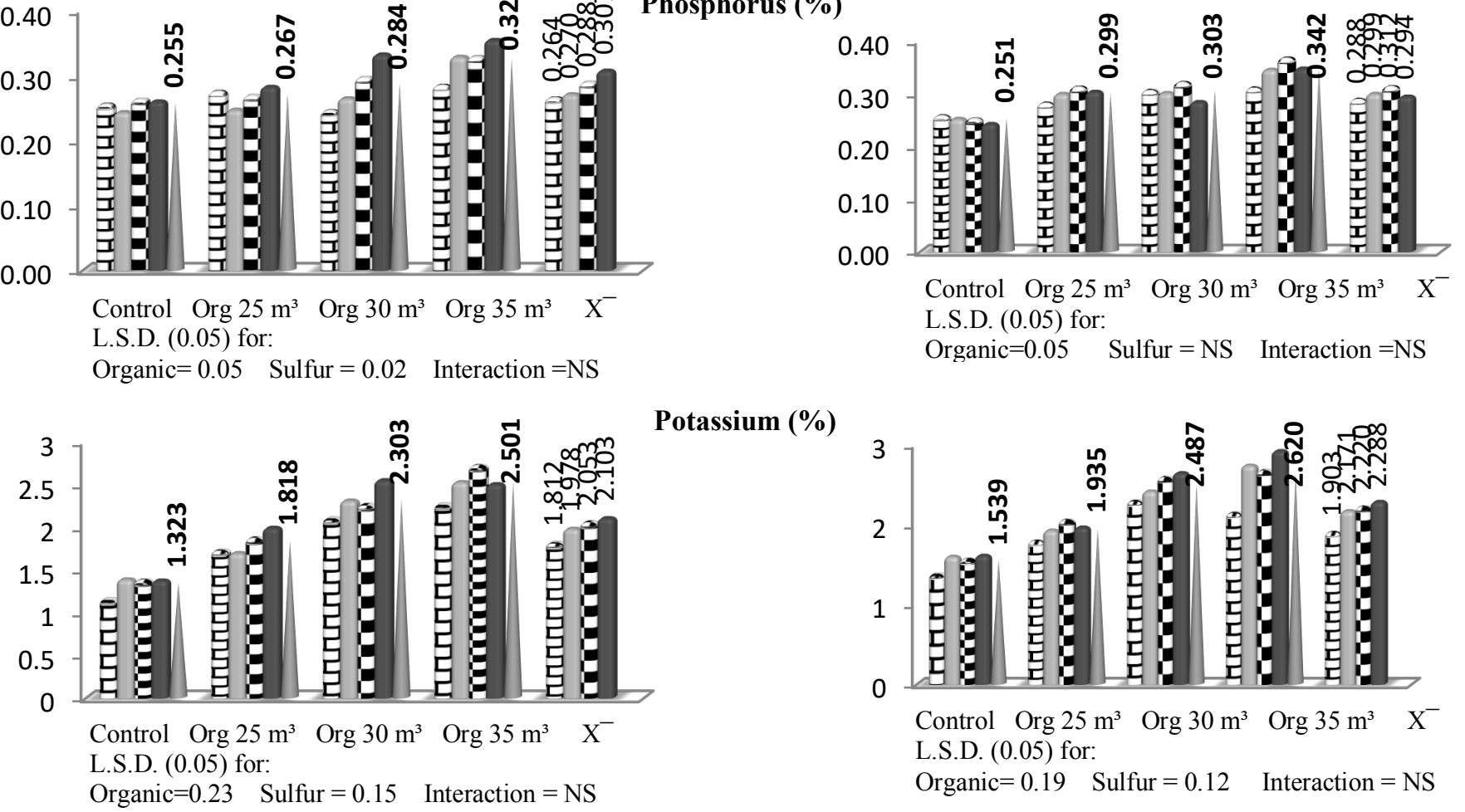

Potassium (\%)

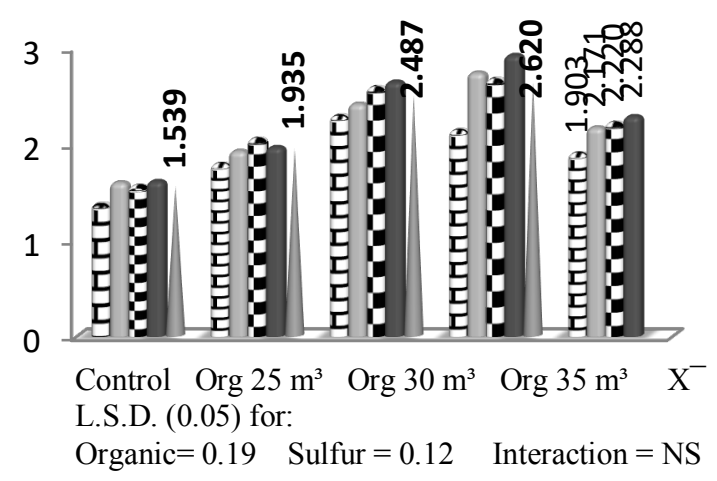

Fig (1): Effect of organic manure and sulfur on N; P and K (\%) of bean plants during 2018/2019 and 2019/2020 growing seasons.

四Control $\square$ Sulfur $100 \mathrm{~kg} / \mathrm{fed}$. $\mathbf{E}$ Sulfur $150 \mathrm{~kg} / \mathrm{fed}$. Sulfur $200 \mathrm{~kg} /$ fed. 


\section{REFERENCES}

Abbas, M. A. Ismail, M. El-gamal and H. Salem (2011). Integrated effect of mineral nitrogen, bio and organic fertilization on soybean productivity, Egypt. J. Biotechnol., 39: 43-63.

Ali, Aisha H., M.R. Shafeek, Asmaa R. Mahmoud and M. El-Desuki (2014). Effect of various levels of organic fertilizer and humic acid on the growth and roots quality of turnip plants (Brassica rapa). Current Science International, 3 (1): 7-14.

Brown, J.D. and O. Lilliland (1964). Rapid determination of potassium and sodium in plant material and soil extracts by flame photometer. Proc. Amer. Soc. Hort. Sci., 48: 341-346.

Cottenie, A., M. Verloo, L. Kickens, G. Velghe and R. Camerlynck (1982). In: "Chemical Analysis of Plants and Soils." Laboratory of Analytical and Agrochemistry. State Univ., Ghent Belgium, 63 p.

Doran, J. (1995). Building soil quality. In: Proceedings of the 1995 Conservation Workshop on "Opportunities and Challenges in Sustainable Agriculture". Red Dear, Alta, Canada, Alberta Tillage Conservation Society and Alberta Agriculture Conservation, Development Branch, pp. 151-158.

Drinkwater, L.E., D.K. Letournean, F. Workneh, A.H.C. van Bruggen and C. Shennan (1995). Fundamental differences between conventional and organic tomato agroecosystems in California. Ecol. Appl., 5: 1098- 1112.

El-Banna, E.B. (1998). In: "Soil Mechanics and Water". $1^{\text {st }}$ Ed., El-Bardi Press, Mansoura, $444 \mathrm{p}$.

Farid, I.M., M.H.H. Abbas and E. Fawzy (2014). Rationalizing the use of water of salinity hazards for irrigating maize grown in a saline sodic soil. Egypt. J. Soil Sci., 54 (2): 163-175.

Farid, I.M., M.H.H. Abbas and A.M. El-Ghozoli (2018). Implications of humic, fulvic and $\mathrm{K}$ humate extracted from each of compost and biogas manures as well as their teas on faba bean plants grown on a typic torripsamment soil and emissions of soil $\mathrm{CO}_{2}$. Egypt. J. Soil Sci., 58 (3): $275-289$.

Głowacka, A., T. Gruszecki, B. Szostak and S. Michałek (2019). The response of common bean to sulphur and molybdenum fertilization. Int. J. Agron., 3830712.

Hegab, A.S.A, M.T. Fayed, Maha M.A. Hamada and M.A.A. Abdrabbo (2014). Productivity and irrigation requirements of faba-bean in North Delta of Egypt in relation to planting dates. Annals of Agricultural Sciences, 59 (2): 185-193.

Herencia, J.F., J.C. Ruiz, S. Melero, Garcia P.A. Galavís and C.A. Maqueda (2008). Short-term comparison of organic v. conventional agriculture

Egyptian J. Desert Res., 70, No. 2, 137-151 (2020) 
in a silty loam soil using two organic amendments. J. Agric. Sci., 146 (6): 677-687.

Jensen, E.S., M.B. Peoples and H. Nielsen (2010). Faba bean in cropping systems. Field Crops Research, 115: 203-216.

Kaiser, B.N., K.L. Gridley, J.N. Brady, T. Phillips and S.D. Tyerman (2005). The role of molybdenum in agricultural plant production. Ann. Bot., 96: 745-754.

Kamel, G.H., E. Noufal, I.M. Farid, S. AbdelAziz and M.H.H. Abbas (2016). Allivating salinity and sodicity by adding some soil amendments. J. Soil Sci. Agric. Eng., Mansoura Univ.,7 (6): 389-395.

Klute, A.J. (1986). In: "Methods of Soil Analysis". No. (9), Part 1, Physical and Mineralogical Methods. Am. Soc., Agron., Inc. Soil. Sci., Mad., Wisc., U.S.A.

Lange, A. (1998). Einfluß der Schwefel-Versorgung auf die biologische Stickstoff Fixierung von Leguminosen. PhD Thesis, University of Bonn, Germany.

Mendel, R.R. and F. Bittner (2006). Cell biology of molybdenum. Biochim. Biophys. Acta, 1763: 621-635.

Ministry of Agriculture and Land Reclamation (2006). Statistical Year Book, Central administration for agricultural economics. Study of important indicators of the agricultural statics, 2: $61 \mathrm{p}$.

Mukherjee, D. and R.K. Singh (2002). Influence of sulphur, iron and silicon nutrition on growth and yield of irrigated mustard. Haryana J. Agron., 18 (1\&2): 50-2.

Nalle, C.L., V. Ravindran and G. Ravindran (2010). Nutritional value of faba beans (Vicia faba L.) for broilers: Apparent metabolisable energy, ileal amino acid digestibility and production performance. Animal Feed Science and Technology, 156: 104-111.

Nassib, A.M., S.A. Khalil and A.H.A. Hussein (1991). Faba bean production and consumption in Egypt. Options Méditerranéennes, 10: 127-131.

Niewiadomska, A., P. Barłóg, K. Borowiak and A. Wolna-Maruwka (2015). The effect of sulphur and potassium fertilization on the nitrogenase and microbial activity in soil under broad bean (Vicia faba L.) cultivation. Fresenius Environ. Bull., 24: 723-732.

Nzuma, J.K., S. Mpepereki and H.K. Murwira (1998). Cattle Manure Management Option for Reducing Nutrient Losses: Farmer Perceptions and Solutions in Mangwende, Zimbabwe. In: "Soil Fertility Research for Maize-Based Farming Systems in Malawi". Waddington, S., H.K. Murwira, J. Kumwenda, D. Hikwa and F. Tagwira Eds., Harare: CIMMYT, pp. 183-90.

Osama, A.M. (2015). Role of humic substances and compost tea in improvement of endogenous hormones content, flowering and yield and its components of faba bean (Vicia faba L.). Annals Agric. Sci., Moshtohor, 53 (3): 373-384. 
Page, A.L., R.H. Miller and D.R. Keeney (1982). In: "Methods of Soil Analysis". No. (9), Part 2. Chemical and Microbiological Properties. Am. Soc., Agron., Inc. Soil. Sci., Mad., Wisc., U.S.A.

Scherer, H.W. and A. Lange (1996). $\mathrm{N}_{2}$ fixation and growth of legumes as affected by sulphur fertilization. Biol. Fert. Soils, 23: 449-53.

Sexton, P.J., W.D. Batchelor and R. Shibles (1998). Soybean sulfur and nitrogen balance under varying levels of available sulfur. Crop Sci., 38: 975-982.

Singh, A.K., R.C. Bharati, N.C. Manuibhushan, A. Pedpati (2013). An assessment of faba bean (Vicia faba L.) current status and future prospect. Biology, Medicine Journal of Environmental Biology, ID: 4656785.

Singh, M.S. (2005). Effects of rhizobium, FYM and chemical fertilizers on legume crops and nutrient status of soil: a review. Agric. Rev., 26: 309-312.

Souza, R.F., V. Faquin, R.R.L. Sobrinho and E.A.B. Oliveira (2010). Influence of cattle manure and limestone on residual effects of phosphorus fertilizer in Brachiaria brizantha grown after common bean. Rev. Bras. Ciênc. Solo., 34: 143-50.

Stamatiadis, S., M. Werner and M. Buchnam (1999). Field assessment of soil quality as affected by compost and fertilizer application in a broccoli field (SanBenito County, California). Appl. Soil Ecol., 12: 217-225.

Stratton, M.L., A.V. Barker and J.E. Rechcigl (1995). Compost. In: "Soil Amendments and Environmental Quality". Rechcigl, J.E. (Ed.). Lewis Publishers, London. pp. 249-310.

Tabe, L. and T. Higgins (1998). Engineering plant protein composition for improved nutrition. Trends Plant Sci., 3: 282-296.

Tadele, B., S. Zemach and L. Alemu (2016). Response of faba bean (Vicia $f a b a \mathrm{~L}$.) to phosphorus fertilizer and farm yard manure on acid soils in Boloso sore woreda, Wolaita zone, southern Ethiopia. Food Sci. Qual. Manag., 53: 15-21.

Thomas, M.L. and F.G. Hills (1975). In: "Statistical Methods in Agric. Research". Univ. of California, Davis $956162^{\text {nd }}$ printing, pp. 6774.

Tiwari, K.N. (2002). Nutrient management for sustainable agriculture. J. Indian Soc. Soil Sci., 50 (4): 374-397.

Köpke, U. and T. Nemecek (2010). Ecological services of faba bean. Field Crops Research. 115 (3): 217-233.

Zhou, L.I., J. Cao, F.S. Zhang and L. Li (2009). Rhizosphere acidification of faba bean, soybean and maize. Sci. Total Environ., 407: 4359-4362.

Egyptian J. Desert Res., 70, No. 2, 137-151 (2020) 


\section{تأثير معدلات السماد العضوي والكبريث على نمو وانتاجية الفول الرومي تحت ظروف جنوب سيناء}

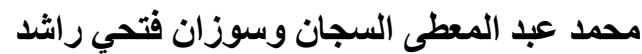

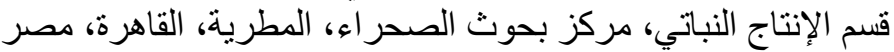

أجريت الدر اسة بمزرعة خاصة بمدينة الطور بمحافظة جنوب سيناء خلال موسيمين شتوين

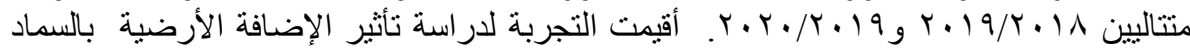

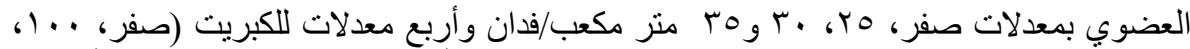

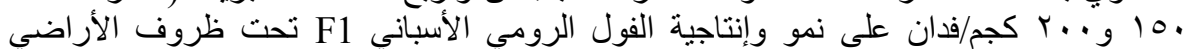

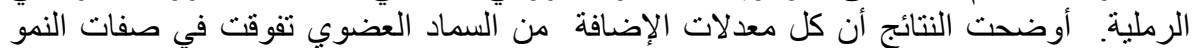

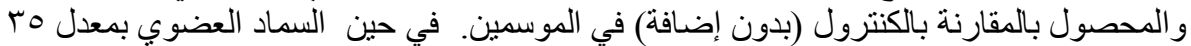

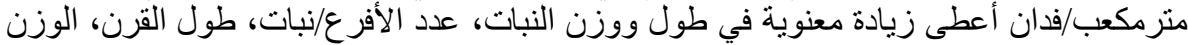

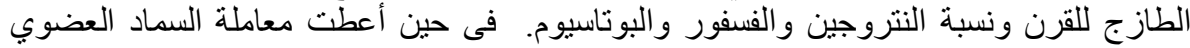

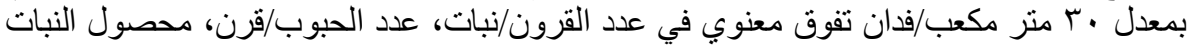

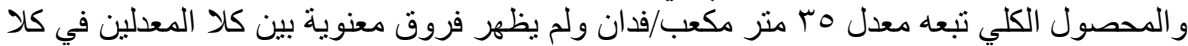

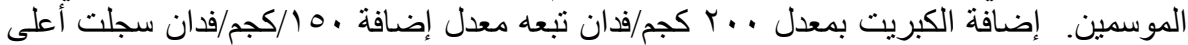

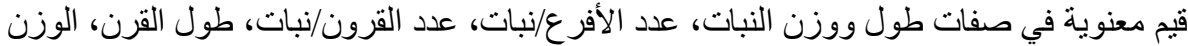

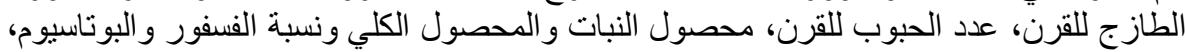
ولم يظهر فروق معنوية بين كلا المعدلين في كلا الموسمين.

Egyptian J. Desert Res., 70, No. 2, 137-151 (2020) 